\title{
A Course in the Mathematics of Design
}

\author{
by Jay M. Kappraff
}

Topologie Structurale \#8, 1983

\author{
Un cours en mathématiques du design
}

Il y a 5 ans, plusieurs mathématiciens, architectes et spécialistes en informatique du New Jersey Institute of Technology commencèrent à explorer des domaines présentant un intérêt commun. Les architectes cherchaient des façons d'agrandir leur répertoire limité de formes et de structures architecturales, ils cherchaient un langage qui exprimerait certaines notions vagues telles que la "symétrie", la "complexité" ou le "système optimal", et finalement ils souhaitèrent développer les compétences mathématiques nécessaires pour rendre les travaux de design architectural plus opérationnels. Les mathématiciens essayaient de trouver des applications intéressantes pour des domaines des mathématiques qui sont par ailleurs abstraits tels que la théorie de groupes, la topologie et la théorie des graphes, et de plus, ils voulaient redécouvrir les racines géométriques de leur sujet. Les spécialistes de l'informatique virent les étudiants en architecture comme des utilisateurs éventuels des ordinateurs, particulièrement pour les graphiquess faits à l'aide d'ordinateurs. Grâce à ces intérêts mutuels, des discussions animées s'ensuivirent qui débouchèrent en premier lieu sur un séminaire couronné de succès donné à l'intérieur du programme de troisième année d'architecture et finalement, sur un nouveau cours obligatoire d'un semestre orienté vers les projets en Mathématiques du design, donné à un nombre de 80 à 100 étudiants de première année d'architecture. Notre groupe prépara un reccueil de notes qui fut récemment révisé pour en faire l'ébauche d'un manuel formel qui serait un parallèle au cours. Nous venons tout juste de donner ce cours pour la quatrième fois,

Five years ago several mathematicians, architects, and computer scientists at the New Jersey Institute of Technology began to explore areas of common interest. The architects were trying to find ways to break out of their limited repertoire of architectural forms and shapes, they were looking for a language to express certain vague notions such as "symmetry", "complexity", or "optimal systems", and finally they wished to develop the mathematical skills necessary to make architectural design tasks more operational. The mathematicians were trying to find some interesting applications for otherwise abstract branches of mathematics such as group theory, topology and graph theory and in addition they wanted to rediscover the geometrical roots of their subject. The computer scientists saw the architecture students as a potential user of computers in particular computer graphics. As a result of these mutual interests, lively discussions ensued which led first to a successful seminar given as part of the third year architecture studio and finally to a new required project oriented one semester course in the Mathematics of Design given to between 80 and 100 first year architecture students. Our group prepared a set of Notes which has recently been refined into the draft of a formal textbook that closely parallels the course. We have just finished teaching this course for the fourth time, and we would like to describe it and share some of our experiences teaching the course. 


\section{Le cour a trois objectifs:}

- présenter à l'étudiant des outils mathématiques pour le design spatial;

- à travers les mathématiques, suggérer des idées intéressantes et originales pour le design spatial;

- de montrer à l'étudiant que le design spatial n'est pas le résultat de combines gratuites, mais qu'il est régi par certaines propriétés mathématiques de l'espace.

Le cours est constitué de quatre parties. La première partie traite de certains éléments de géométrie dans le plan, la seconde partie nous amène à la géométrie tridimensionnelle, la troisième partie du cours couvre certains aspects de la structure de la géométrie, tandis que la dernière partie étudie plusieurs applications des mathématiques pour résoudre des problèmes de complexité. Dans l'Appendice A, nous donnons la liste des sujets couverts dans chacune de ces parties (toutefois, il n'y a pas assez de temps pour couvrir tous les sujets dans un seul semestre).

Chaque partie du cours conduit à l'exécution de courts projets de design. Quoique les projets soient restreints par les idées mathématiques sous-jacentes, ils sont sans limite en ce qui a trait à l'exécution des designs, et les étudiants sont également encouragés à modifier les exercices en autant que les idées de base sont sauvegardées. De cette manière, les réponses des étudiants à ces travaux présentent une grande diversité. Les étudiants doivent apporter le même soin qu'un architecte ou un artiste prendrait au cours de leurs projets et ils sont cotés tout aussi bien sur leur connaissance du métier que sur la créativité de leurs designs.

Il y a habituellement, au premier abord, une certaine réticence de la part des étudiants à entreprendre des constructions pour lesquelles les indications sont quelque peu libres. Ils ne voient pas toujours les travaux demandés comme une façon d'encourager leurs habiletés créatrices. Toutefois, à mesure que le semestre progresse et que les étudiants observent les projets de haute qualité et d'ingénuité réalisés par leurs pairs, nous observons une qualité de travail plus élevée produit par les étudiants. Ce cours nous permet également d'identifier quelques étudiants ayant des talents extraordinaires en design. Ces étudiants produisent de réelles oeuvres d'art dignes d'exposition et, comme résultat, notre cours sert à nous indiquer quels sont les étudiants qui seront les meilleurs designers dans les ateliers d'architecture au cours des dernières années. L'Appendice $B$ donne la liste des projets proposés au cours des années où nous avons donné le cours.

Même si le développement d'une grande partie de notre matériel a été réalisé en lorgnant du côté de l'application pour ordinateurs, l'absence générale de connaissances au sujet des ordinateurs chez la majorité des étudiants de première année, ainsi que les limites de temps, ont exclus l'intégration de l'ordinateur directement dans le cours.

La moitié de la note de l'étudiant est basée sur les projets tandis que le reste se répartit entre des examens, des travaux et un travail de session. Cela offre aux étudiants ayant des difficultés dans les formulations analytiques des mathématiques, la possibilité de démontrer leurs connaissancés à travers des projets bien exécutés, tandis que les étudiants ayant peu d'habiletés pour le design peuvent également réussir en maîtrisant les concepts mathématiques à un niveau plus abstrait. Toutefois, notre expérience semble indiquer que les étudiants qui produisent les designs les plus intéressants réussissent également bien dans leur travail analytique.
The course has three objectives:

- to present the student with some mathematical tools of spatial design;

- through the mathematics to suggest some interesting and novel ideas for spatial design;

- to show the student that spatial design is not entirely free wheeling, but it is constrained by certain mathematical properties of space.

The course consists of four part. The first part deals with some elements of geometry in the plane, the second part gets into the geometry of 3-dimensions, the third part of the course covers some aspects of the structure of geometry, while the last part studies several applications of mathematics to organizing complexity. In Appendix A we list the topics covered by each of these parts (although there is not enough time to cover all topics in one semester).

Each part of the course leads to the execution of short design projects. Although the projects are constrained by the underlying mathematical ideas, they are open ended in terms of the execution of the designs, and students are also encouraged to modify the exercises so long as the basic ideas are preserved. In this way, the responses from the students to the assignments generally show a rich diversity. The students are expected to use the care of an architect or artist in carrying out their projects, and they are graded on both the craftmanship and creativity of their designs.

There is usually reluctance on the part of students, at first, to carrying out constructions in which the guidelines were somewhat free. They do not always see our assignments as an opportunity to indulge their creative abilities. However, as the semester progresses and students observe projects of high quality and ingenuity generated by their peers, we find a much higher level of work produced by the students. This course also enables us to identify a few students with extraordinary design talents. These students produce real works of art worthy of exhibition and, as a result, our course serves as an excellent early predictor of the students that turn out to be the best designers in the architecture studios of the later years. Appendix B lists the projects that have been assigned over the years that we have taught the course.

Although development of much of our material has been carried out with an eye toward computer application, the general lack of knowledge about computers on the part of the most of first year students, and limitations of time, have precluded our integration of the computer directly into the course.

Half of the student's grade is based on the projects while the rest of the grade results from examinations, homework, and a term paper. This gives students who have difficulty dealing with the analytical formulations of mathematics an opportunity to demonstrate their understanding of the ideas through well executed projects, whereas students with poor design skills can still succeed by mastering the mathematical concepts on a more abstract level. However, our experience seems to indicate that students who carry out the most interesting designs usually also do well in their analytical work. 
Le reste de cet article est consacré à décrire certains des sujets couverts par notre cours et à illustrer quelques projets résultant de ces sujets.

Le nombre d'or a été une source d'inspiration et d'étude pour les mathématiciens, les artistes, les architectes et les biologistes depuis le temps des Egyptiens [1]. Nous débutons notre semestre avec l'étude du nombre d'or et comment il est relié à la croissance en spirale des coquillages, aux cornes des animaux à cornes, et aux plantes $[2,3]$. Toutefois, notre principal objectif est de présenter aux étudiants le système de proportionalité de Le Corbusier, basé sur le nombre d'or, qu'il a appelé Modulaire [4]. En construisant un ensemble de rectangles à l'aide de longueurs et de largeurs tirées de's séries modulaires de longueurs, les propriétés du nombre d'or $[1,5,6]$ garantissent que tout espace rectangulaire peut être rempli par cette famille de rectangles constituants très proches parents les uns des autres, d'un très grand nombre de façons avec une marge d'erreurs quelconque donnée. La planche 1 montre deux réponses de nos étudiants à un exercice de design basé sur le modulaire.

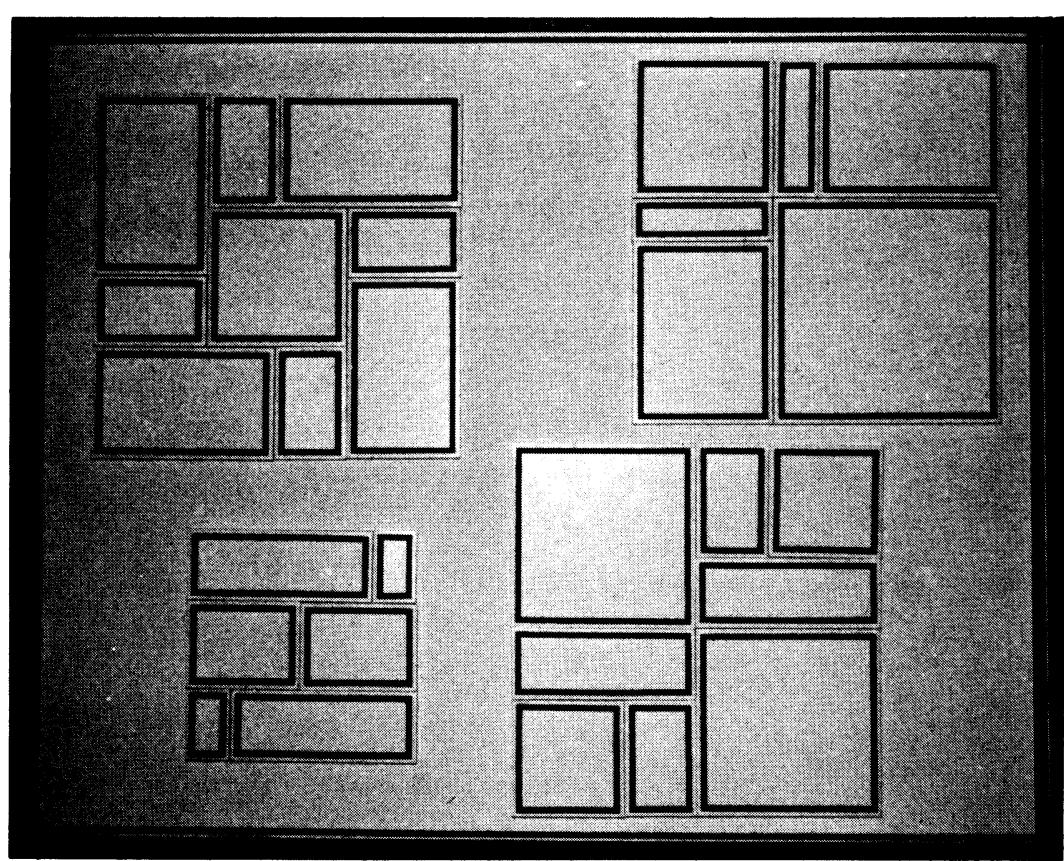

Plate 1a

La discussion sur les tuilages modulaires est précédée d'une courte introduction aux tuilages en général. La planche 2 montre le résultat du tuilage d'un rectangle par des carrés non-congruents [7]. Cela demande à l'étudiant de résoudre d'abord un problème algébrique pour déterminer la taille des carrés. La planche 3 illustre un tuilage non-périodique du plan par deux tuiles basé sur le nombre d'or, connues comme étant un cerf-volant et une flèche [8]. Ces tuilages, imaginés par Roger Penrose, présentent toujours une symétrie pentagonale approximative parmi d'autres propriétés
The remainder of this article is devoted to describing some of the topics covered in our course and illustrating a few projects that resulted from these topics.

The golden mean has been a source of inspiration and study for mathematicians, artists, architects, and biologists since the time of the Egyptians [1]. We begin our semester with a study of the golden mean and how it is related to the spiral growth of shells, horns of horned animals, and plants $[2,3]$. However, our main objective is to introduce students to Le Corbusier's system of proportionality, which he called the Modular [4], based the golden mean. By constructing a set of rectangles with lengths and widths from the modular series of lengths, the properties of the golden mean $[1,5,6]$ insure that any rectangular area can be filled to any given tolerance in an enormous variety of ways by this family of closely related component rectangles. Plate 1 shows two responses of our students to a design exercise based on the modular.

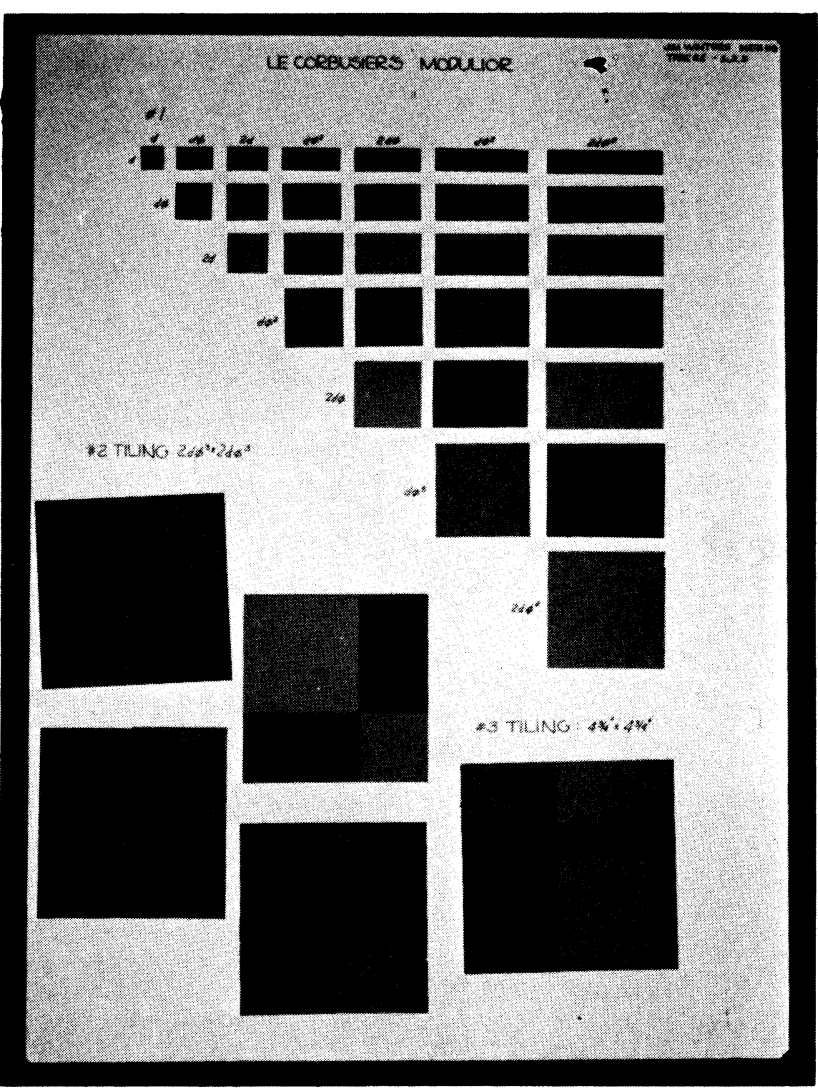

Plate 1b

The discussion of the Modular tilings is prefaced by a short introduction to tilings in general. Plate 2 shows the result of the tiling of a rectangle by non-congruent squares [7]. It requires the student to first solve an algebraic problem to determine the size of squares. Plate 3 illustrates a non-periodic tiling of the plane by two tiles based on the golden mean, known as a kite and a dart [8]. These tilings, devised by Roger Penrose, always have approximate pentagonal symmetry among other interesting mathematical properties. 


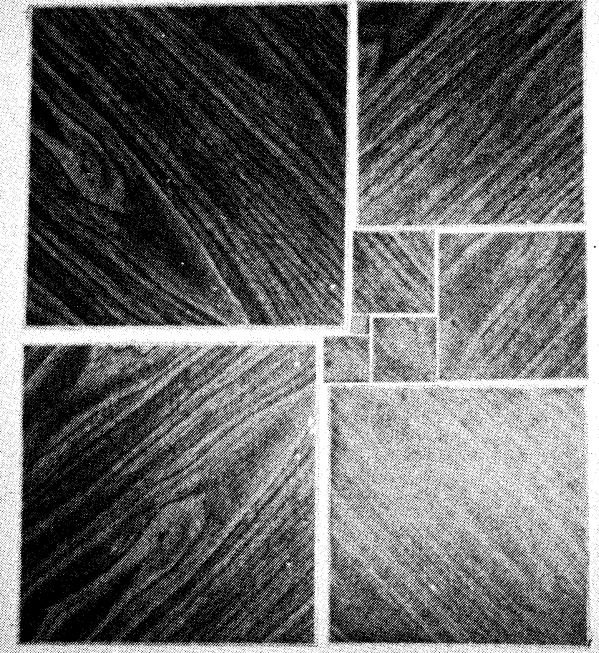

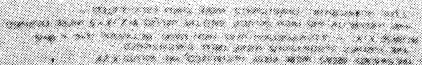

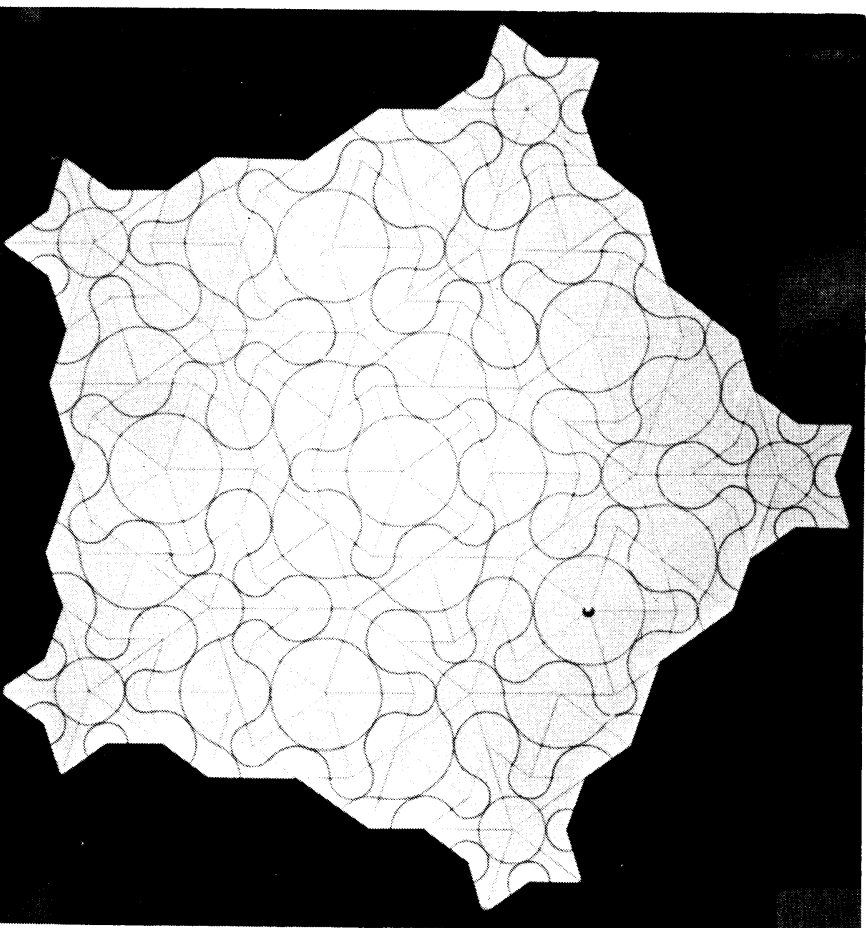

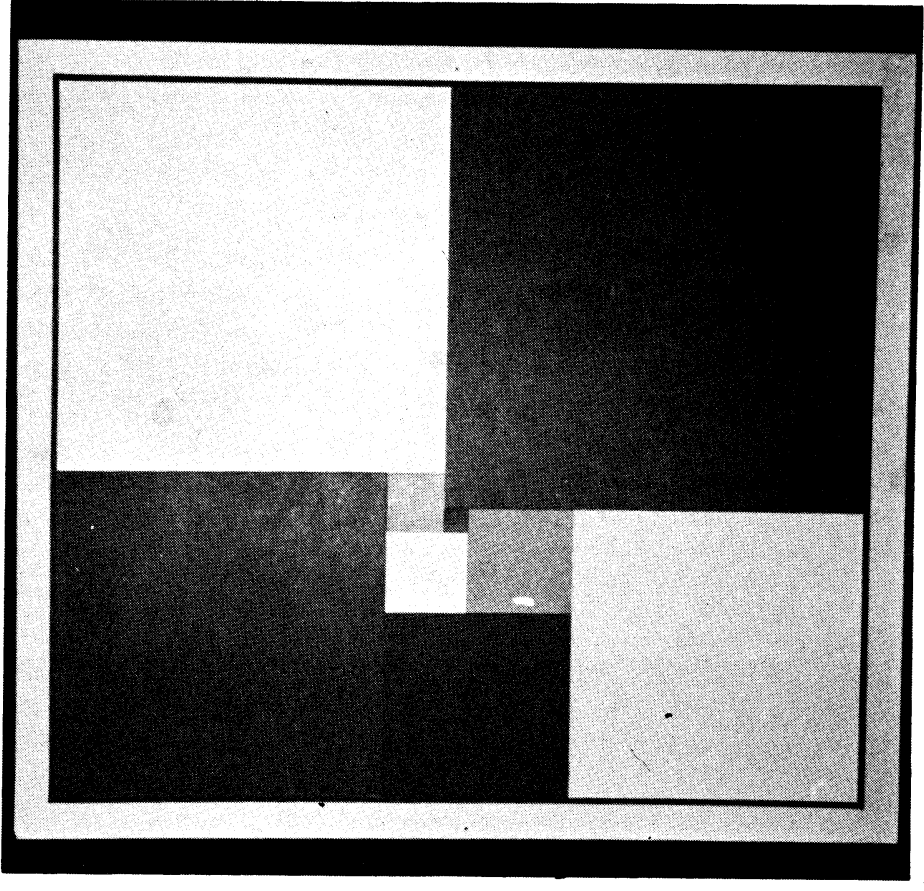

Plate 2b

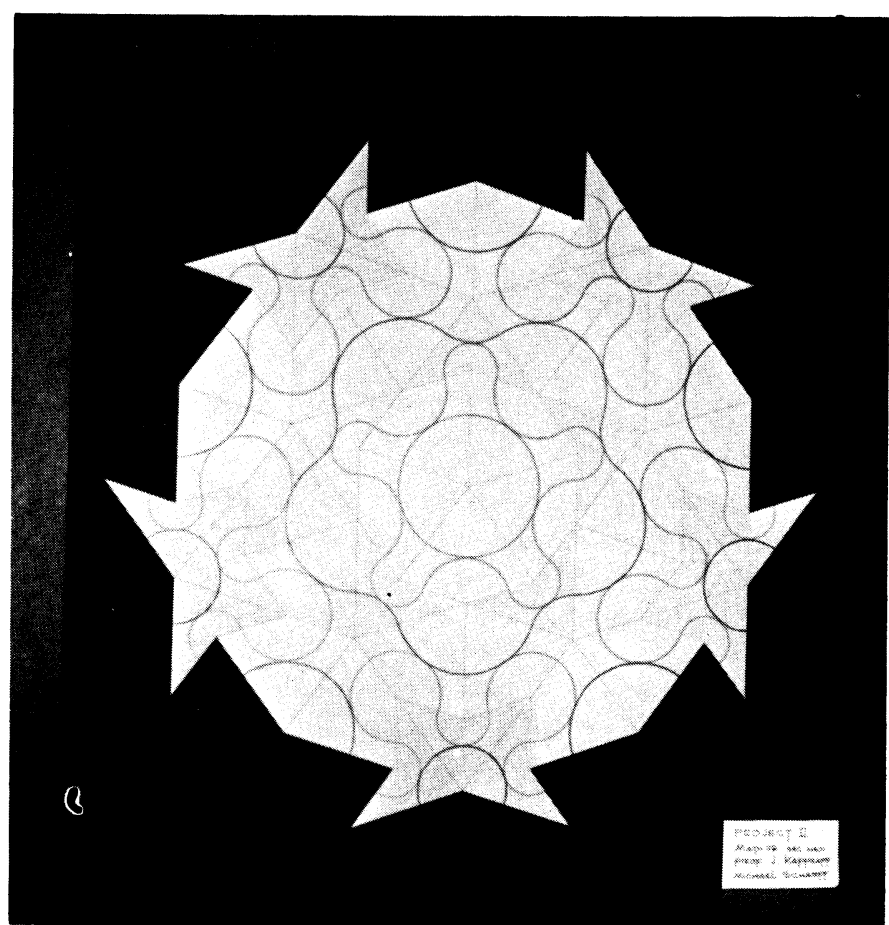

Plate 3a

Plate 3b 
A ce moment. nous trousons andageus d'introduire la notion de tuilage du plan

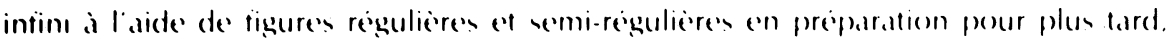

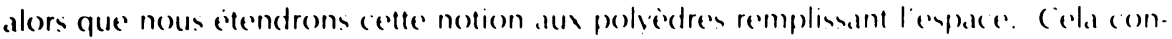
duit naturellement a une discussion sur les treillis plandires ed len domainen de l Diric hled associes a ces treillis, où le domane de Dirichlet d'un point choisi parmi un ensemble de points est desini comme eitant ces points dans le plan qui sont plus pres du point choisi que de tous less autres points dans l'ensemble. Il est bien connu cque le demaine de Dirichlet de tout point d'un treillis peut tout aussi bien être un heragone ou un rece tangle, dependant de l'arrangement des points dans le treillis $|9|$. Comme l'hexagone est un exemple d'un zonagone $|10|$ remplissant l'espace, il peut remplir le plan par une translation en une varietes de tailles, mais possedant des angles internes identicfues, tel que demontré a la planche 4. Cela nous donne une bonne introduction au sujet des plus importants des zonaèdres remplissant l'espace dans l'espace tridimensionnel. La planche 5 explore une autre manière de transtormer un tuilage en son tuilage dual.

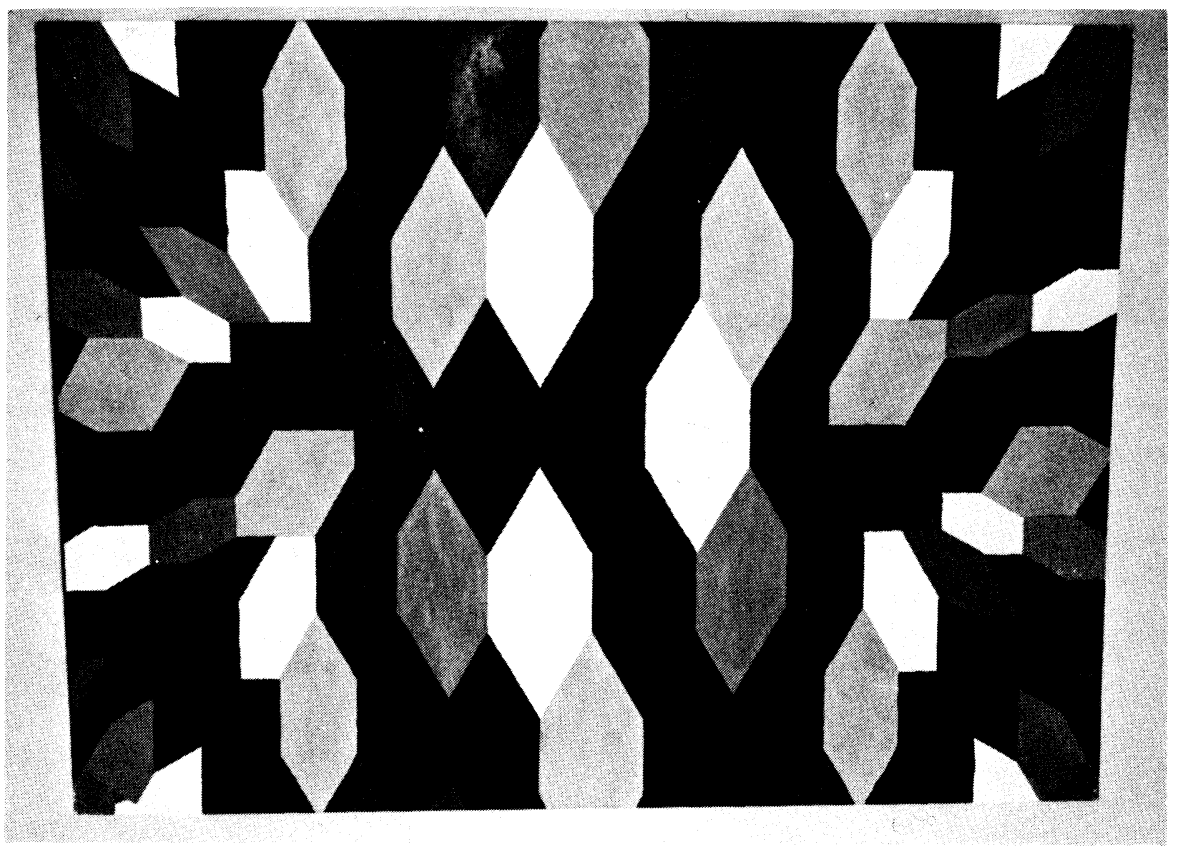

Plate 4

A venir jusqu'à présent, nous nous sommes concentrés sur la géométrie du plan. Nous entrons maintenant dans une analyse de l'espace tridimensionnel. Une brève étude des classes des solides, prismes et antiprismes platoniciens et archimédiens aide les étudiants à construire leur intuition spatiale. Nous mettons l'accent sur les notions de dualité, de symétrie, de remplissage de l'espace, de remplissage dense et de structure en treillis des solide's et sur les ensembles de solides [10]. Notre but est de montrer aux étudiants comment ces solides sont inter-reliés et comment certaines notions mathématiques peuvent les aider à voir, à travers la complexité visuelle de ces objets, leur simplicité structurale sous-jacente. Notre objectif en donnant cette partie du cours
At this point we find it advantageous to introduce the notion of tiling the infinite plane with regular and semiregular figures in preparation to later on, extending this notion to space-filling polyhedra. This leads naturally to a discussion of planar lattices and the Dirichlet domains associated with these lattices, where the Dirichlet domain of a point chosen from a set of points is defined as those points in the plane nearer to the chosen point than to any of the other points in the set. It is well known that the Dirichlet domain of any point of a lattice can be either a hexagon or a rectangle depending on the arrangement of points in the lattice [9]. Since the hexagon is an example of a spacefilling zonagon [10], it can fill the plane by translation with a variety of sizes but identical internal angles as shown in Plate 4. This gives us a good lead into the more important topic of space-filling zonahedra $[11,12]$ in 3-D space. Plate 5 explores another way of transforming a tiling into its dual tiling.

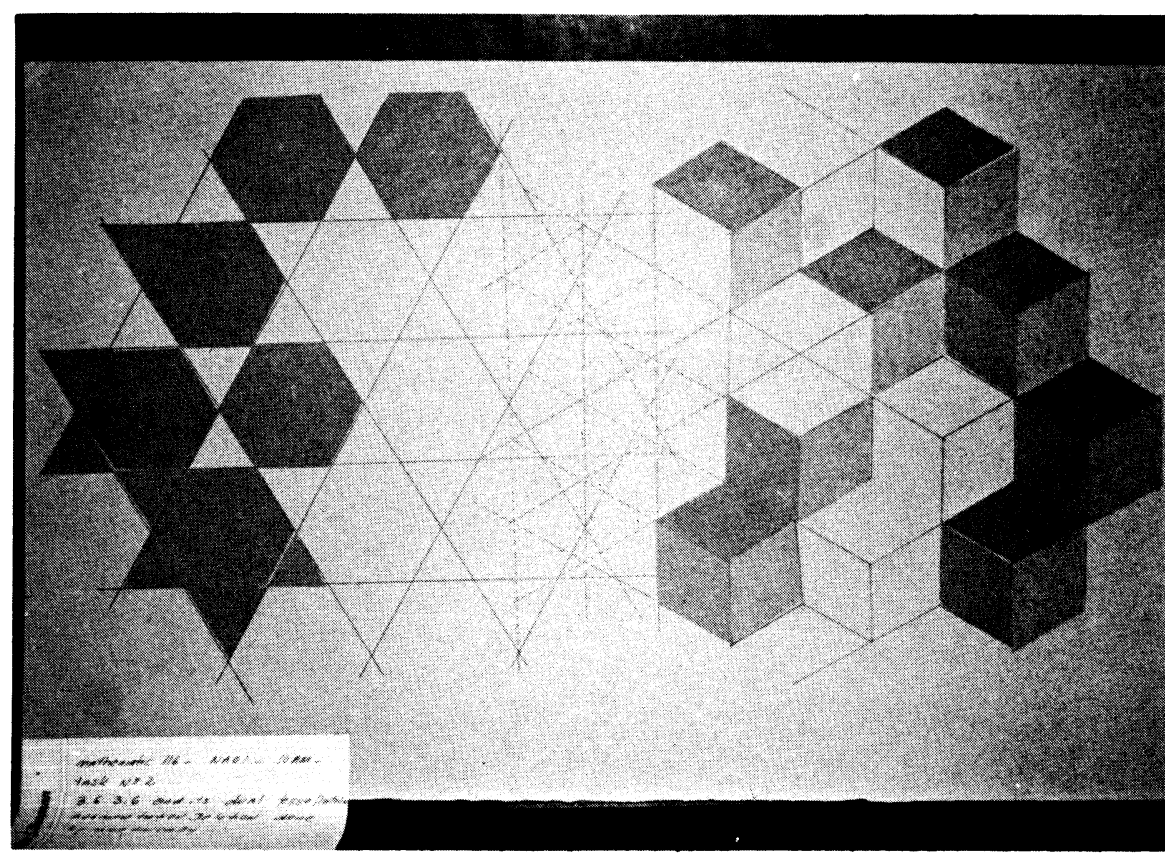

Plate 5

Up to this point we have concentrated on the geometry of the plane. We now enter into an analysis of three-dimensional space. A brief study of the classes of Platonic, Archimedean solids, prisms and antiprisms helps the students to build their spatial intuition. We focus on the notions of duality, symmetry, space-filling, close-packing and lattice structure of the solids and aggregates of solids [10]. Our aim is to show students how these solids are interrelated and how certain mathematical notions can help them to see through the visual complexity of these objects to their underlying structural simplicity. Our tendency in teaching this portion of the course is to, more and more, lead the students to carrying out constructive spatial exercises using sets of rods and rubber connectors [13] and a set of sticks and connectors invented by Peter Pearce which he 
spatiale en utilisant des ensembles de tringles et de connecteurs de caloutchouc [13] et un ensemble de bâtons et de connecteurs invéntés par Peter Pearce qu'il nomme le système de noeuds universel $|14,15|$. Les bâtons et les connecteurs du système de noeuds universel sont de formes et de couleurs codées correspondant aux directions d'arêtes, de diagonale de face, et de diagonale spatiale du cube, ce qui permet une construction très rapide de tout polyèdre du système cubique. Les planches 6, 7 et 8 illustrent certains projets résultant de cette phase du cours. La planche 6 montre une tenségrité dans lacquelle les membres de tension reposent sur lès arêtes d'un cuboctaèdre tandis que len membres de compression forment quatre triangles équilatéraux s'imbriquant les um dans les autres $[16]$. La planche 7 montre déux résultats d'un exercice dans lequel un type de triangles isocèles est combiné pour former une voûte, basée sur l'antiprisme hexagonal, un semi-dôme et une voûte s'intersectant $[17,18]$. Dans la planche 8, des tétraèdrés et des octaèdres sont combinés pour créer une charpente spatiale avec courbures. Finalement, la planche 9 montre deux exemples de la classe de surfaces régulières infinies de Michael Burt $[19,20]$. Ces surfaces divisent l'espace en deux ensembles de tunnels reliés traversés par un treillis de cristal et son treillis dual, c'est-à-dire, le treillis cubique auto-dual de la planche 9a et le treillis cubique corps-centré et son dual à la planche $\mathbf{9 b}$. La régularité signifie que chaque sommet est entouré de façon identique et qu'alors la surface peut être construite à partir d'une répétition de modules identiques. calls the universal node system $[14,15]$. Both sticks and connectors of the universal node system are color and shape coded according the edge, face-diagonal, and bodydiagonal directions of the cube which enables very rapid construction of all polyhedra from the cubic system. Plates 6, 7 and 8 , illustrate some projects resulting from this phase of the course. Plate 6 shows a tensegrity in which the tension members lie at the edges of a cuboctahedron while the compression members form four interlocking equilateral triangles [16]. Plate 7 shows two results of an exercise in which one type of isosceles triangles is combined to form a vault, based on the hexagonal antiprism, a semidome and an intersecting vault $[17,18]$. In Plate 8, tetrahedra and octahedra are combined to create a space truss with curvature. Finally Plate 9 shows two examples of the class of infinite regular surfaces studied by Michael Burt $[19,20]$. These surfaces divide space into two connected sets of tunnels spanned by a crystal lattice and its dual lattice, e.g., the self-dual cubic lattice in Plate 9a and the body centered cubic lattice and its dual in Plate $\mathbf{9 b}$. The regularity means that each vertex is rurrounded identically and thus the surface can be constructed from a repetition of identical modules.

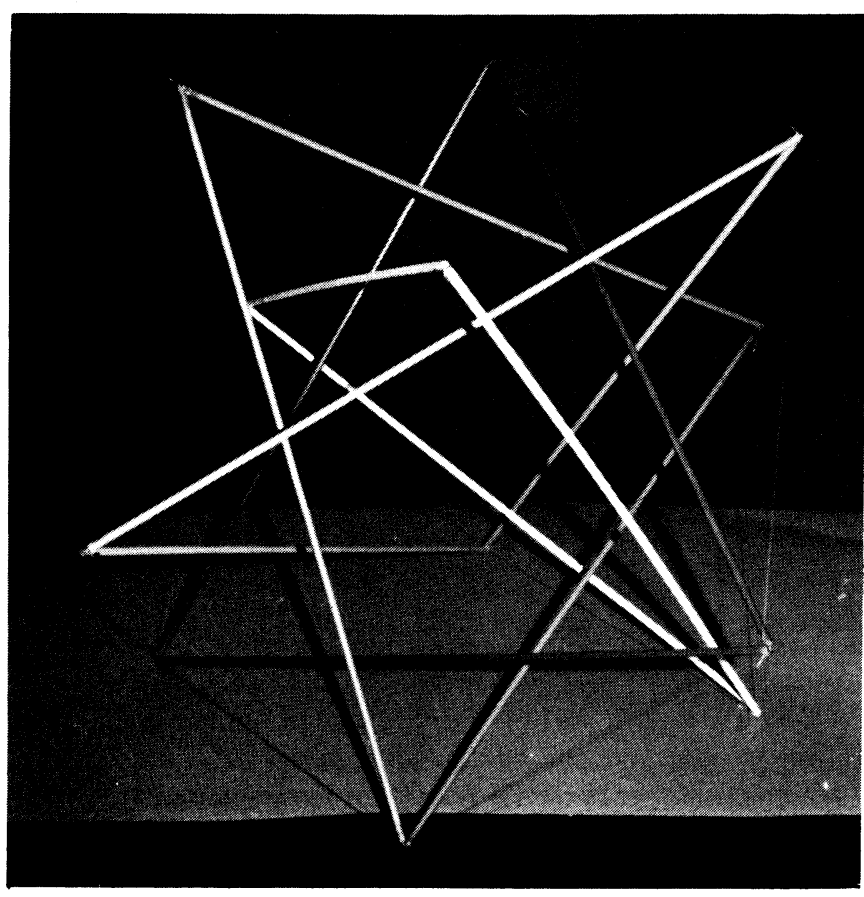

Plate 6

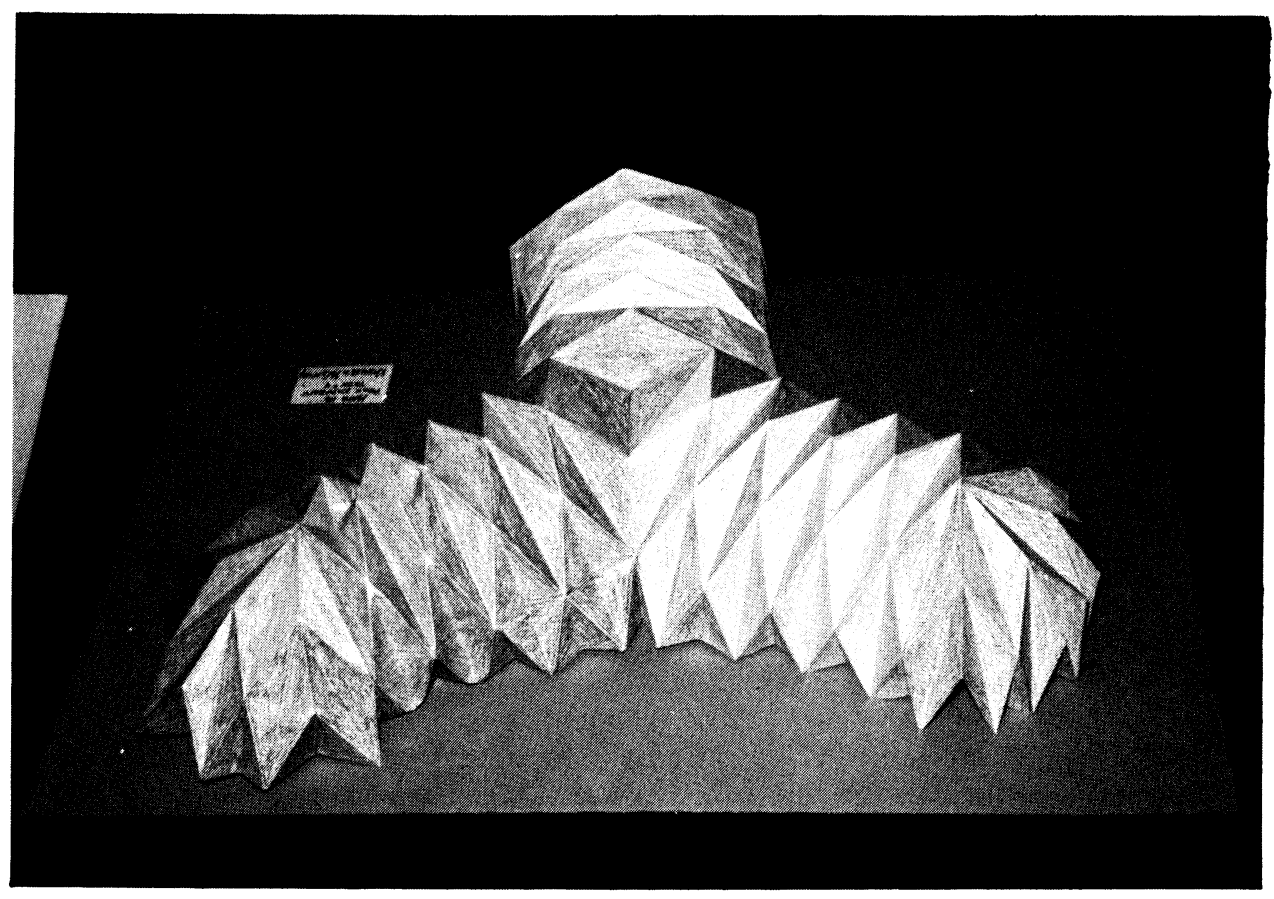

Plate 7a 
I ce stade du cours, nous avons trouvé un film de Ron Resch [21], intitulé "The Paper and Stick Thing Film", qui fut une réelle inspiration pour les étudiants. Resch montre comment un devoir d'étudiant ayant pour but d'étudier comment le papier se chiffonne l'amena à la découverte d'une nouvelle classe de structures qu'il étudia d'abord en construisant des modèles de construction concrets et par la suite, en construisant des modèles' graphiques à l'ordinateur, lorsque les structures atteignirent un niveau de complexité trop grand. Ce film met les étudiants dans un bon état d'esprit pour entreprendre leurs propres constructions. Le film nous fournit également une bonne raison pour présenter aux étudiants les possibilités qu' offrent les ordinateurs de notre école dans l'élaboration de graphiques.

Jusqu'à maintenant, l'enseignement est d'abord qualitatif ou constructif, bien qu'il nous donne l'opportunité d'introduire plusieurs idées de base en géométrie plane et en géométrie des solides. Toutefois, nous avons présenté jusqu'à maintenant à l'étudiant un certain nombre de formes intéressantes qui peuvent servir de matériel de base pour une recherche quantitative. Le cube unitaire sert comme un système coordonné idéal pour étudier le concept de vecteurs libres, où le vecteur est identifié par le triple des coordonnées que sa pointe intersecte lorsque sa queue repose à l'origine. Comme tous les solides réguliers et semi-réguliers du système cubique sont construits avec des arêtes qui sont, soit orientées le long de l'arête, soit des diagonales de face ou des diagonales spatiales du cube, à l'aide des concepts vectoriels des produits scalaires et vectoriels, on peut calculer les angles diédriques de ces solides et cela nous amène aux critères déterminant les propriétés de remplissage de l'espace des solides. Nos modèles, construits à partir du système de noeuds universel de Peter Pearce, deviennent très utiles. Suite à cette approche concrète de l'analyse vectorielle, plusieurs de nos étudiants réussissent à apprendre les fondements de ce sujet à l'intérieur d'une couple de semaines tout en ayant un très grand niveau de compréhension. Les étudiants apprennent alors comment on peut décrire les lignes et les plans à l'aide de vecteurs, ce qui nous amène à une discussion sur les surfaces réglées. Les intersections de lignes et de plans sont à la base de la description mathématique des hyperboloïdes de révolution (HR) et des paraboloïdes hyperboliques (HP), tous deux étant formés par l'enveloppe d'une famille infinie de lignes générées par l'intersection avec trois lignes obliques [22]. D'autres descriptions locales des HP et des HR résultent de leurs relations avec le quadrilatère gauche et l'hexagone gauche respectivement $[6,23,24]$. Nos étudiants furent encouragés à incorporer ces surfaces réglées dans une suggestion de design d'un immeuble. La planche 10 nous montre le résultat de deux de ces travaux.

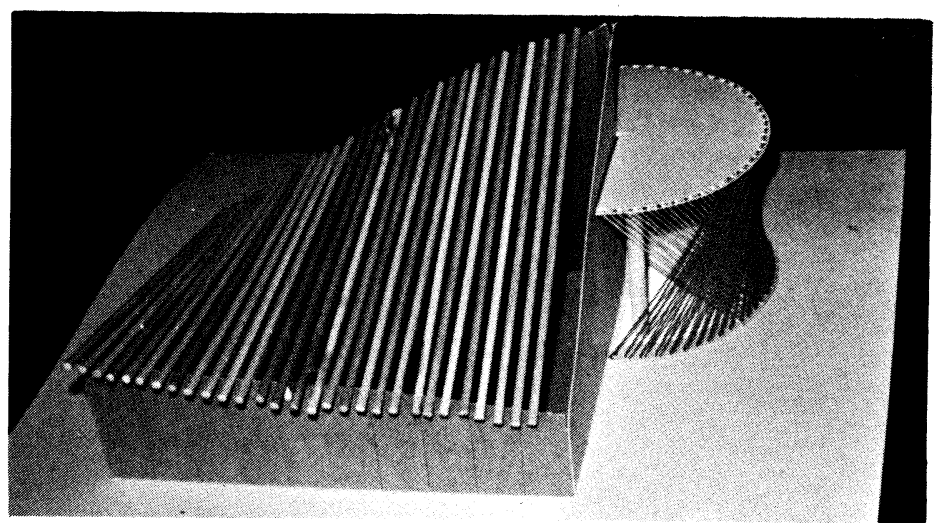

At this stage of the course we find a film by Ron Resch [21] called "The Paper and Stick Thing Film" to be a real inspiration to the students. Resch shows how a student assignment to study how paper crumbles led him to a discovery of a new class of structures which he first studied by building physical models and then by constructing computer graphics models when the structures reached an unmanageable level of complexity. This film puts the students in a good frame of mind to carry out their own constructions. The film also gives us incentive to introduce the students to our school's computer graphics facilities.

Up to this point, the instruction is primarily qualitative or constructive, although it gives us the opportunity to introduce several basic ideas from plane and solid geometry. However, the student has been introduced by now to a number of interesting shapes which can serve as raw material for a quantitative investigation. The unit cube serves as an ideal coordinate system in which to study the concept of free vectors, where the vector is named by the triple of coordinates that its tip intersects when its tail lies at the origin. Since all regular and semiregular solids from the cubic system are constructed with edges that are either oriented along the edge, face-diagonal or body-diagonal of the cube, with the aid of vector concepts of dot and cross-product, dihedral angles of these solids can be computed and these lead to criteria for space-filling properties of solids. Our models, built with the universal node system of Peter Pearce, come in handy. As a result of this concrete approach to vector analysis, many of our students are able to learn about the fundamentals of this subject in only a couple of weeks at a high level of understanding. The students then learn how lines and planes can be described using vectors which leads us to a discussion of ruled surfaces. Intersections of lines and planes lie at the basis of the mathematical description of hyperboloids of revolution (HR) and hyperbolic paraboloids (HP) each of which is formed by the envelope of an infinite family of lines generated by intersection with three skew lines [22]. Further local descriptions of the HP and the HR follow from their relations to the skew quadrilateral and the skew hexagon $[6,23,24]$ respectively. Our students were encouraged to incorporate these ruled surfaces into a design suggestive of a building. Two results are shown in Plate 10.

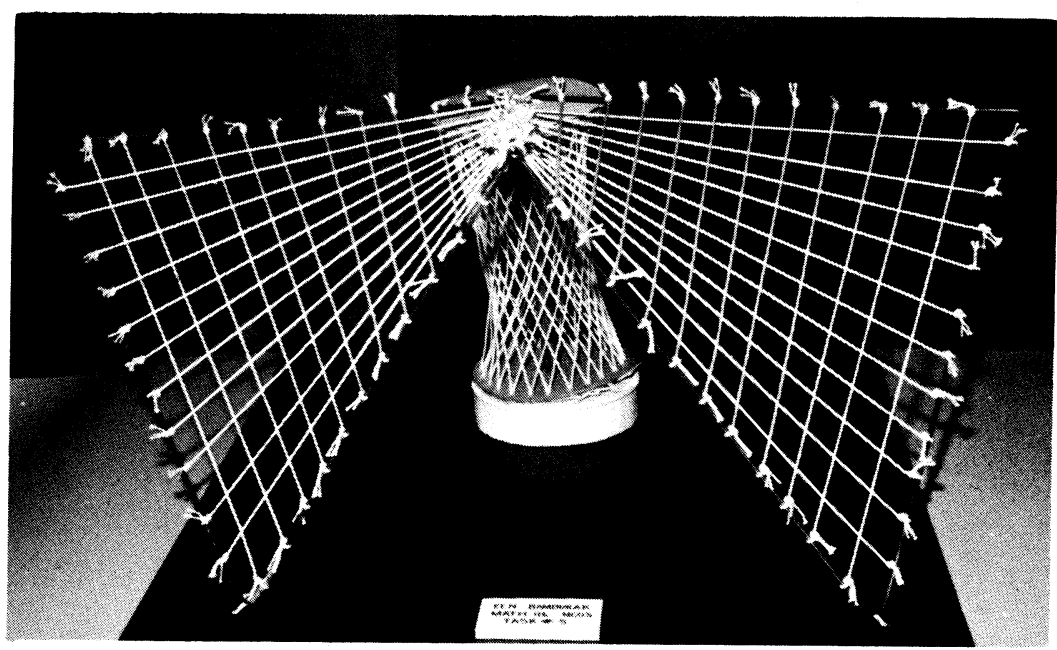


L'étape suivante du cours traite de la symétrie par une approche mathématique de la notion de symétrie, c'est-à-dire l'étude des transformations qui laissent invariant un ensemble de points dans l'espace. Afin de pouvoir traiter de ce concept, nous consacrons un certain temps à développer leur bagage mathématique. Nous donnons d'abord une définition mathématique précise de la transformation, et nous discutons par la suite brièvement du programme Erlangen de Felix Klein, qui démontre comment la hiérarchie des géométries: euclidienne $=>$ affine $\Rightarrow>$ projective $=>$ la topologie sont définies par des ensembles correspondants de transformations qui conservent: la distance et l'angle, le parallélisme, le rapport double et les voisinages de points, dans cet ordre.

La plus générale des géométries, $C^{\prime}$ est-à-dire la topologie, conserve certaines propriétés telles que la caractéristique de Euler-Poincaré, $\chi$, où $\chi=V-E+F$, et le nombre chromatique (le plus grand nombre de couleurs nécessaires pour colorier une mappemonde de telle sorte qu'il n'y ait pas deux pays adjacents qui soient de la même couleur). Ces idées sont illustrées à la planche 11 par un polyèdre de Szilassi [25] qui est un polyèdre ayant la connectivité d'un tore dans lequel chacune de ses sept faces borde les six autres, ce qui démontre alors que le nombre chromatique d'un tore est au moins 7 .

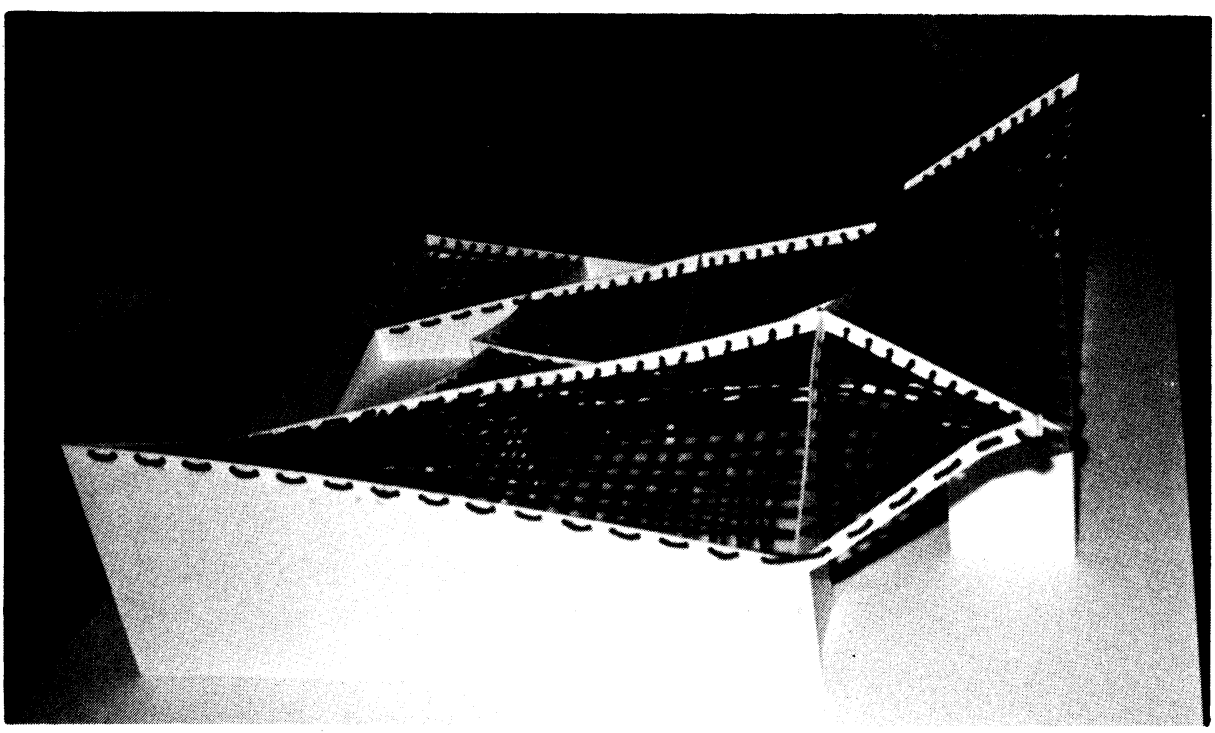

Plate 10c

Le reste de notre discussion sur la symétrie traite de l'invariance d'ensemble de points sous rotations, translations, réflexions et translations-réflexions, c'est-à-dire les isométries. On aborde ce sujet en présentant un excellent film [26] qui, de pair avec notre discussion, démontre comment les rotations et les translations sont généréés par paires de réflexions, de deux types, où les miroirs s'intersectent dans un point où l'angle de rotation est deux fois l'angle entre les miroirs, et l'autre se produisant lorsque les miroirs sont parallèles où la translation est deux fois la distance qu'il y a entre les miroirs. Finalement, trois miroirs qui ne sont pas tous parallèles ou qui ne s'intersectent pas à un point génèrent une translation-réflexion. Ces mouvements sont démon-
The next phase of the course deals with symmetry approached through the mathematical notion of symmetry, i.e. the study of those transformations that leave a set of points in space invariant. In order to deal with this concept, some time is devoted to developing the mathematical equipment. We first give a precise mathematical definition of a transformation, and then briefly discuss Felix Klein's Erlangen program which shows how the hierarchy of geometries: Euclidean $\Rightarrow$ Affine $\Rightarrow$ Projection $\Rightarrow$ Topology are defined by corresponding sets of transformations which preserve: distance and angle, parallelism, cross-ratio, and neighborhoods of points, in that order.

The most general of the geometries, namely topology, perserves certain properties such as the Euler - Poincare's characteristic, $\chi$, where $\chi=V-E+F$, and the chromatic number (the greatest number of colors needed to color a map such that no two adjacent courtries have the same color). These ideas are illustrated in Plate $\mathbf{1 1}$ by a Szilassi polyhedron [25] which is a polyhedron with connectivity of a torus in which each of its seven faces borders on the other six and thus demonstrates that the chromatic number for the torus is at least 7.

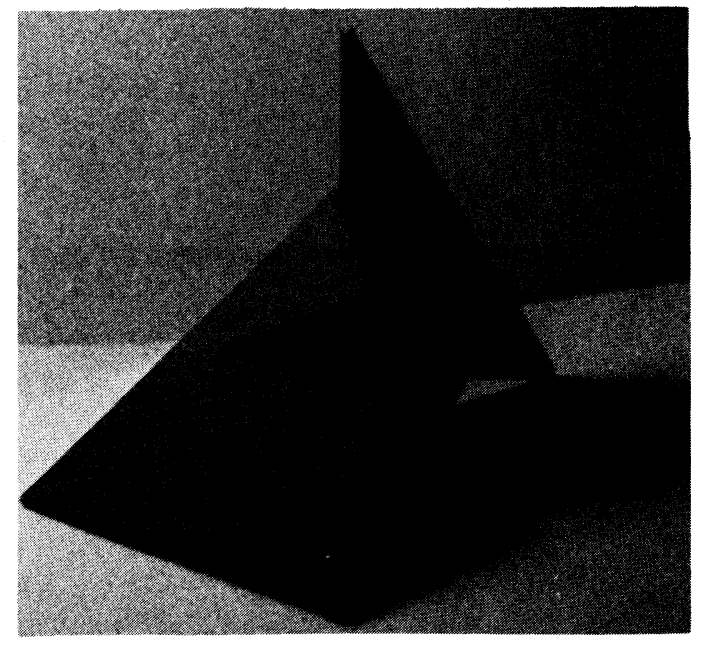

Plate 11

The remainder of our discussion of symmetry deals with invariance of point sets under rotations, translations, reflections and glide reflections, i.e., isometries. This subject is initiated by an excellent film [26] which along with our discussion shows how rotations and translations are generated by pairs of reflections, the former when the mirrors intersect at a point in which case the rotation is through twice the angle between the mirrors, and the latter when the mirrors are parallel in which case the translation is through a distance twice the distance between the mirrors. Finally, three mirrors not all parallel or intersecting at a point generates a glide reflection. These motions are demonstrated both geometrically and experimentally with real mirrors. The students are then asked to start with a figure and repeatedly transform this figure by a sequence 
alors aux étudiants de commencer par une illustration et de transformer cette illustration plusieurs fois par une séquence $d$ 'isométries pour créer un modèle. La planche 12 illustre deux résultats de cet exercice produisant des modèles à deux et à trois dimensions. L'étudiant apprend alors comment les isométries peuvent être générées de façon analytique par les matrices, motivé par la nécessité de programmer un ordinateur pour effectuer ces transformations.

Finalement, nous démontrons l'invariance des ensembles de points dans les groupes diédriques (kaléidoscopiques), les groupes de frises, et les groupes de papier peint, conduit à des symétries correspondantes [5, 27, 28, 29]. La planche 13 illustre deux des 17 modèles possibles de papier peint. Bien que nous ne traitions pas des symétries tridimensionnelles, nous avons toutefois présenté un film sur Les symétries du cube, de H.M.S. Coxeter [30], dans lequel Coxeter démontre comment les trois plans orthogonaux de symétrie du cube et les six plans renfermant les arêtes opposées du cube divisent le cube en 48 cellules tétraédriques congruentes ou énantiomorphiques (congruentes sous réflexion). Par ailleurs, un étudiant a construit une telle cellule à partir de miroirs et a démontré que les opérations du groupe de symétrie peuvent reconstruire un cube entier à partir d'une cellule placée à l'intérieur de ce kaléidoscope, tel qu'illustré à la planche 14. Ceci termine la partie géométrique de notre cours. of isometries to generate a pattern. Plate 12 illustrates two results of this exercise yielding a two and a three dimensional patterns. Now the student learns how isometries can be generated analytically via matrices, motivated by the necessity to instruct a computer to carry out these transformations.

Finally, we show how invariance of point sets under dihedral (kaleidoscopic) groups, frieze groups, and wallpaper groups leads to the corresponding symmetries [5, 27, 28, 29]. Plate 13 shows two of the 17 possible wallpaper patterns. Although we do not deal with 3-D symmetries, we did show a film on The Symmetries of the Cube by H.M.S. Coxeter [30] in which Coxeter demonstrates how the three orthogonal planes of symmetry of the cube and the six planes containing opposite edges of the cube divide the cube into 48 congruent or enantiomorphic (congruent under reflection) tetrahedral cells. Furthermore, a student constructed one such cell out of mirrors and showed that the symmetry group operations would reconstruct an entire cube from one cell placed inside this kaleidoscope as shown in Plate 14. This concludes the geometric portion of our course.
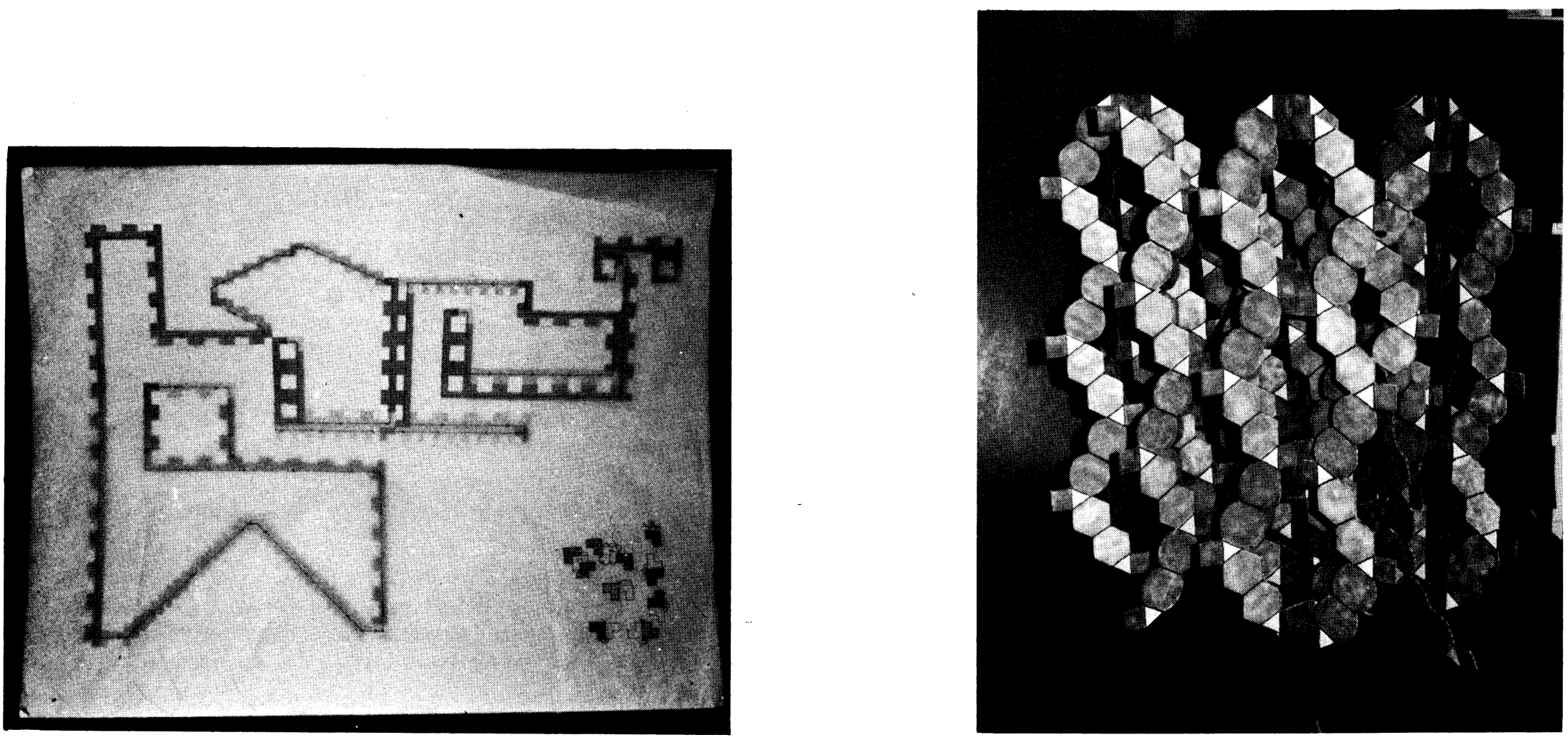


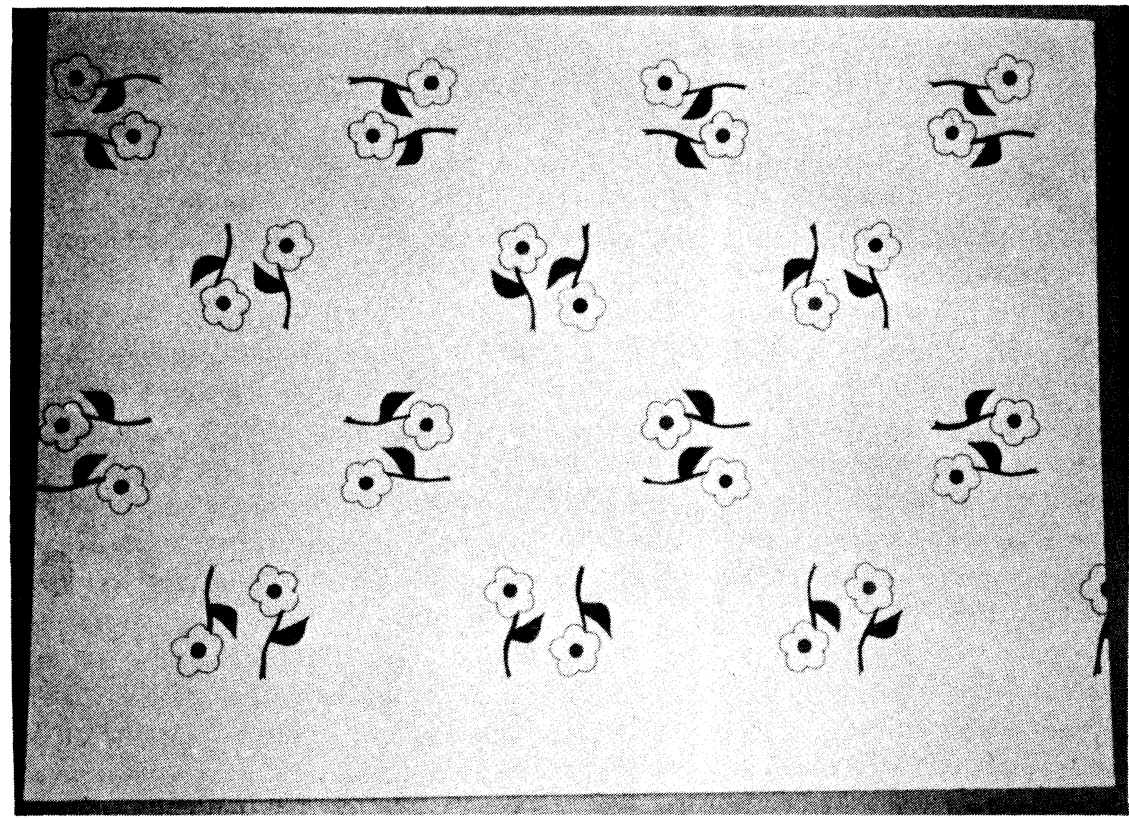

Plate 13a

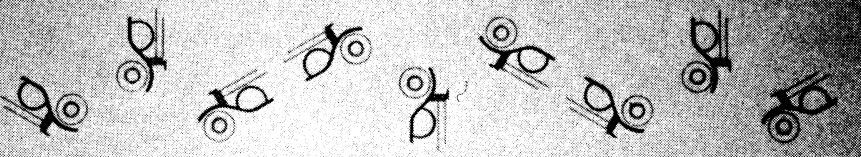

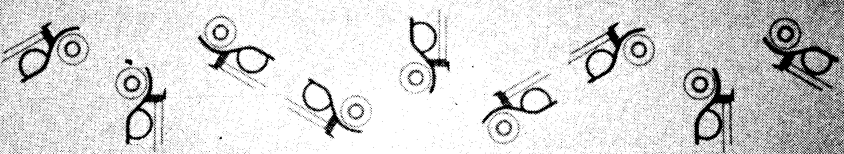

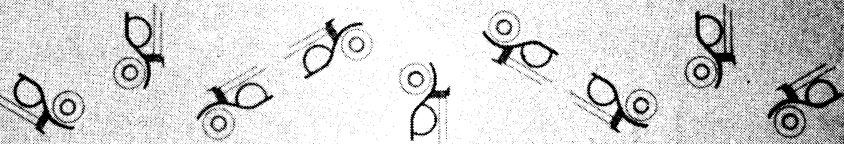

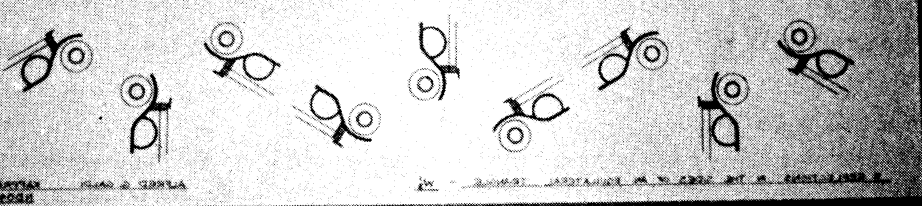

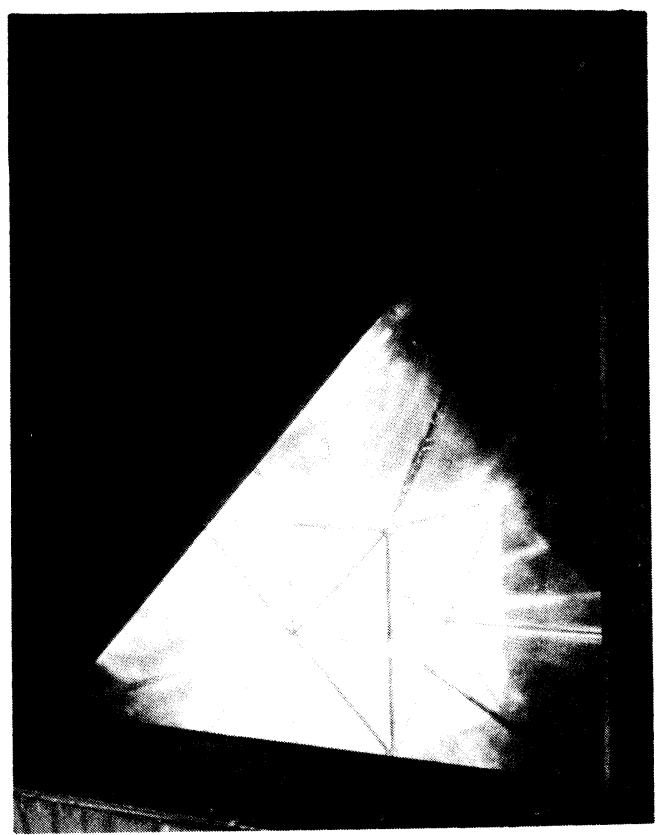

Plate 14 
Nous avons développé plusieurs modules d'enseignement pour la partie du cours traitant de la complexité. Durant un semestre, nous avons habituellement le temps d'aborder un seul de ces sujets. Une partie du cours traite de plusieurs applications des graphes. Le problème du fameux pont de Königsberg introduit le concept du cycle de Hamilton, où le problème des "utilités" [31] traite de la notion des graphes planaires et non-planaires. Les analyses des diagrammes de Schlegel sur les solides de Platon et les rhombidodécaèdres démontrent que le premier possède des cycles de Hamilton tandis que le dernier n'en a pas. La stratégie gagnante pour le casse-tête des "Tours d'Hanoi, dans lequel un ensemble d'anneaux de tailles inégales doivent tous être transférés à partir d'une des trois positions à une autre position, à condition qu' un grand anneau ne repose jamais en haut d'un anneau de taille inférieure, est apparentée aux cycles de Hamilton des arêtes d'un cube $\mathrm{N}$-dimensionnel [25]. Certains étudiants s'amusèrent à construire des cubes quadri-dimensionnels. Après cette brève introduction, les étudiants apprennent comment dessiner un graphe adjacent et à formuler des matrices adjacentes pour les pièces d'une maison [5] dans laquelle chaque pièce est représentée par un sommet, deux sommets étant reliés si leurs pièces respectives ont un mur mitoyen. Le graphe dual, bien entendu, représentant le plan de la maison. Nous avons demandé comme projet de travail de refaire le design de la maison Aline Devine de Frank Lloyd Wright à partir d'un graphe non-planaire à un graphe planaire tel qu'illustré à la planche 15. Au dernier semestre, nous avons eu quelque temps pour introduire l'analyse du cheminement critique [32]; nous avons demandé aux étudiants de faire le graphique d'un ensemble donné d'opérations nécessaires à la construction d'un voilier hypothétique et nous leur avons demandé d'essayer de déterminer le temps minimum requis pour achever la tâche, en donnant le temps requis pour chaque opération. Finalement, nous avons familiarisé les étudiants avec l'algorithme PERT pour effectuer ce problème à l'aide de l'ordinateur. En disposant d'un peu plus de temps, nous aurions pu démontrer comment, par une modification de cet algorithme impliquant des approximations successives, nous pourrions calculer le cheminement le plus court à l'aide d'un graphe arbitraire [32]. We have developed several instructional modules for the portion of the course dealing
with complexity. During any semester we generally have time for only one such unit. One sequence deals with several applications of graphs. The famous Konigsberg bridge problem introduces the concept of the Hamilton cycle while the utilities problem [31] deals with the notion of planar and non-planar graphs. Analysis of the Schlegel diagrams of the platonic solids and the rhombicdodecahedron show that the former have Hamilton cycles while the latter does not. The winning strategy for the "Towers of Hanoi» puzzle in which a set of rings of unequal sizes must all be transfered from one of three posts to either of the other posts under the condition that a larger ring never lies atop a ring of smaller size is related to Hamilton cycles of the edges of an $\mathrm{N}$-dimensional cube [25]. Some of the students took pleasure in constructing 4-D cubes. After this short introduction, the students learn how to draw an adjacency graph and formulate adjacency matrices for the rooms in a house [5] in which each room is represented by a vertex and two vertices are connected if their respective rooms share a wall. The dual graph, of course, turns out to be the usual floor plan of the house. We assign a project to redesign the Frank Lloyd Wright Aline Devine house [5] from a non-planar to a planar graph as shown in Plate 15. Last semester there was a little time to introduce critical path analysis [32], we had the students graph a given set of operations needed to construct a hypothetical sailboat and try to determine the shortest time required to carry out the task, given the time required to carry out each operation. Finally, the students were introduced to the PERT algorithm to do this problem computationally. With a little more time we could show how a modification of this algorithm involving successive approximations, enables one to compute the least time path through an arbitrary graph [32].

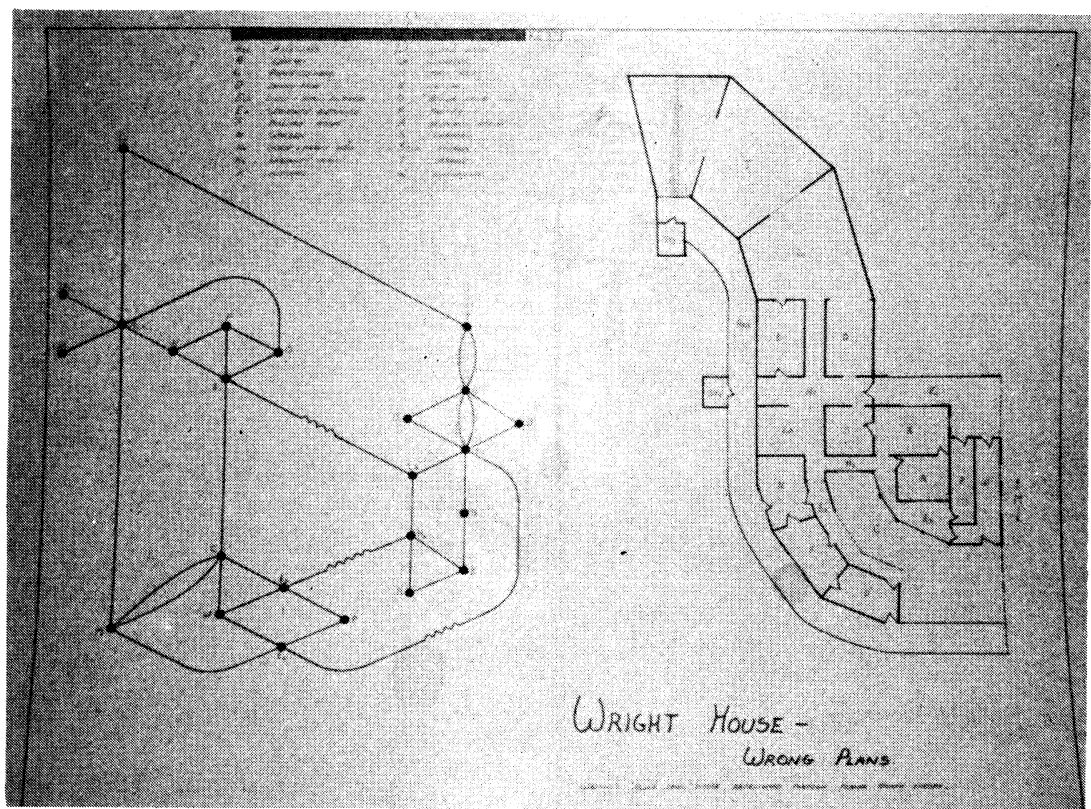


Dans un autre module traitant de complexité, nous avons demandé aux étudiants de résoudre le problème de la localisation d'un dispensaire d'hôpital à un emplacement situé dans un quadrillage de rues de telle sorte que la somme des distances pondérées à partir du dispensaire jusqu'à un ensemble de $\mathrm{N}$ hôpitaux, en utilisant les distances au long des rues, a une valeur minimum et où les hôpitaux sont pondérés selon leur importance $[6,33]$. Ce problème donne une solution graphique élégante, et comporte une application directe pour les architectes. Plusieurs de nos étudiants utilisèrent ces idées pour aider à situer l'immeuble de l'administration centrale destiné à un groupement pour un projet en architecture devant être construit dans une carrière abandonnée.

Les étudiants ont généralement bien réagi à ce cours en dépit de son caractère expérimental dans les premières années alors que nous étions à élaborer le cours tout en l'enseignant et en dépit du manque de textes adéquats pour tout le matériel nonstandard. Maintenant que nous avons élaboré un texte adéquat et que nous sommes à écrire un guide pour les enseignants, nous espérons qu'il sera plus facile d'entraîner d'autres enseignants de notre collège pour donner ce cours et pour le diffuser ailleurs. Je serais ravi de correspondre avec d'autres personnes qui tentent de donner des cours semblables au nôtre ou avec toute personne qui serait intéressée à expérimenter notre approche dans son institution.

Finalement, nous devons mentionner honnêtement que le gros de nos efforts dans l'organisation de ce cours a porté surtout sur la formulation de son contenu et sur l'enseignement aux étudiants. De telle sorte qu'il y a eu très peu de diffusion autour de ces idées à l'intérieur du curriculum de l'Ecole d'architecture. Nous espérons faire plus dans les années à venir pour communiquer nos idées à l'intérieur de la Faculté d'architecture.

\section{Appendice A}

Quel est le contenu du cours?

\section{Le design spatial en deux dimensions}

- La similarité dans les mathématiques et dans la nature

- Le nombre d'or

- Le tuilage du plan

- Les domaines de Dirichlet

- Les treillis bi-dimensionnels

\section{Le design spatial en trois dimensions}

- Les solides de Platon (réguliers)

- La dualité

- Les solides archimédiens (semi-réguliers)

- Les prismes et les antiprismes

- Les remplissages denses

- Le système de noeuds universel de Peter Pearce

- Les treillis et les réseaux

- Les surfaces régulières infinies - Burt et al.
Another module on complexity has the students solve the problem of locating a hospital dispensary at a site along a grid of streets such that the sum of the weighted distances from the dispensary to a set of $\mathrm{N}$ hospitals, using a street distance norm, is a minimum where the hospitals are weighted according to importance $[6,33]$. This problem leads to an elegant graphical solution, and has direct application to architects. Several of our students used the ideas to help locate the central administration building for an Architecture project to design a community to be built in an abandoned quarry.

The students have generally responded well to this course in spite of the groping nature of the instruction in its early years as we attempted to develop the course while teaching it and the lack of an adequate text for all the non-standard material. Now that we have developed a useable text, and we are in the process of writing an instructors guide, we hope that it will be easier to train other instructors at our college to teach this course and to replicate it elsewhere. I would be delighted to correspond with others who are attempting to teach courses such as ours or anyone who is interested in trying out this approach in their school.

Finally, we must be honest to mention that most of our efforts in organizing this course have gone into formulating its content and teaching the students. As a result, there has been little diffusion of the ideas into the mainstream of the Architecture School's curriculum. We hope to do more in the coming year to communicate our ideas to the Architecture faculty.

\section{Appendix A}

What is the content of the course?

\section{Spatial design in two-dimensions}

- Similarity in math and nature

- The golden mean

- Tiling of the plane

- Dirichlet domains

- Two dimensional lattices

\section{Spatial design in three-dimensions}

- The platonic solids (regular)

- Duality

- Archimedean solids (semiregular)

- Prisms and antiprisms

- Close packing

- Universal node system of Peter Pearce

- Lattices and networks

- Infinite regular surfaces - Burt et al. 
- Les zonaèdres remplisuant l'eyple"

- Lescharpentery yoltiales

- Les bullenderaron

- Lessurtacen régheses

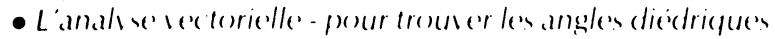

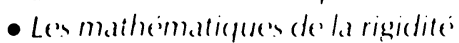

La symétrie et la structure de la géométrie

- Leconcept mathematicue der transtormations

- La hiérarchie des géométries: euclidienne $=>$ affine $=>$ géométrie projective $=>$ topologie

La topologie

- Le nombrede luler-Poincaré

- Lecoloriage de la mappemonde

\section{La géométrie projective}

- La théorie de la perspective pour les artistes

- Les transformations et les conesprojectits

- Les théorèmes de Pascal et de Branchion

\section{Les isométries}

- Création d'isométries planes à l'aide de mircirs

L'application des matrices aux graphiques d'ordinateurs

- Création de translations, de réflexions, de rotations et de projections

\section{La symétrie}

- La symétrie kaléidoscopique

- La symétrie des moulures

- La symétrie des frises

- La symétrie du papier peint

\section{Les mathématiques de la complexité}

\section{Graphs}

- Le graphe des pièces adjacentes d'une maison

- L'analyse du cheminement criticue

- La localisation optimale d'un dispensaire central afin de minimiser la distance à $N$ noeuds pondérée selon l'importance lla distance étant mesurée le long des rues de la ville)

\section{Les mathématiques du chauffage solaire passif}

\section{Appendice B}

\section{Le design spatial à deux dimensions}

- Les tuilages basés sur le «modulaire» de Le Corbusier

- Recouvrir de tuiles un rectangle à carrés non-congruents

- Les transformations de tuilages réguliers du plan

- Un tuilage non-périodique du plan comportant une symétrie pentagonale approximative basée sur le nombre d'or
- Space-filling zonahedra

- Sipace trusses

- Soap bubbles

- Ruled surfaces

- Vector analysis - to find dihedral angles

- Math of rigidity

\section{Symmetry and the structure of geometry}

- The mathematical concept of transformations

- Hierarchy of geometries: Euclidean $=>$ Affine geom. => Projective geom. =>

Topology

Topology

- Euler Poincare number

- Map coloring

\section{Projective geometry}

- Theory of perspective for artists

- Projective transformations and conics

- Pascal's and Branchion's theorems

\section{Isometries}

- Generation of plane isometries using mirrors

\section{Application of matrices to computer graphics}

- Generation of translations, reflections, rotations, and projections

\section{Symmetry}

- Kaleidoscope symmetry

- Molding symmetry

- Frieze symmetry

- Wallpaper symmetry

\section{The mathematics of complexity}

\section{Graphs}

- Adjacency graph of a house

- Critical path analysis

- Optimal location of a central dispensary so as to minimize distance to $\mathrm{N}$-nodes weighted by importance (distance measured .lung city streets)

\section{Mathematics of passive solar heating}

\section{Appendix B}

\section{Spatial design in two-dimensions}

- Tilings based on "the Modular» of Le Corbusier

- Tile a rectangle with non-congruent squares

- Transformations of regular tilings of the plane

- A non-periodic tiling of the plane with approximate pentagonal symmetry based on the golden mean 


\section{Le design spatial à trois dimensions}

- Une construction de forme libre du prot. Anne Tying, basée sur le nombre d'or

- Une comstruction de tenségrites

- La construction d'une voûté, d'un semi-dôme, l'application de l'antiprisme des voûtes s'intersectant

- Less surfaces réglées - intégrer paraboloides hyperboliques et hyperboloides de révolution dans un design d'un ensemble d'immeubles

- Les charpentes spatiales à courbures

- Le's surfaces régulières infinies à structures à treillis

\section{La structure de la géométrie}

- Construire un polyèdre de Szilassi avec la connectivité d'un tore (beigne) pour illustrer le problème des 7 couleurs

- Construire un kaléidoscope diédrique pour illustrer la symétrie du cube

- Transformer une figure en deux ou trois dimensions en utilisant la translation, la rotation, la réflexion ou la translation-réflexion pour obtenir un modèle de symétrie

\section{Les mathématiques de la complexité}

- Refaire le design de la maison Aline Devine de Frank Lloyd Wright à partir d'une structure à graphe non-planaire et à graphe planaire et réaliser le graphe dans un plan architectural

- Analyse du cheminement critique dans la construction d'un voilier

\section{Bibliography}

[1] Ghyka, Matila. The Geometry of Art and Life.

[2] Thomason, D'Arcy. On Growth and Form. Cambridge Press, 1966.

[3] Stevens, Peter. Patterns in Nature. Boston. Little Brown. 1974.

[4] Le Corbusier. Modular. M.I.T. Press, 1955.

[5] March, Lionel and Steadman, Philip. The Geometry of Environment. M.I.T. Press, 1971.

[6] Kappraff, Jay and Blackmore, Denis. The Mathematics of Design. N.J.I.T. Lecture Notes, 1982

[7] Stein, Sherman. Mathematics; the Man Made Universe. Freeman Press, 1963.

[8] Gardner, Martin. Scientific American. January 1978.

[9] Loeb, Arthur L. Space Structures, their Harmony and Counterpoint. Reading, Mass. Addison Wesley, 1976.

\section{Spatial design in three-dimensions}

- A free form construction based on the golden mean of prof. Anne Tyng

- Tensegrity construction

- Construction of a vault, semidome and intersecting vault-application of the antiprism

- Ruled surfaces - integrate hyperbolic parab. and hyperbola of revolution into a design suggestive a building complex

- Space trusses with curvature

- Infinite regular surfaces with lattice structures

\section{The structure of geometry}

- Construct a Szilassi polyhedron with the connectivity of a torus (donut) demonstrating the 7-color problem

- Construct a dihedral kaleidoscope to illustrate the symmetry of the cube

- Transform a figure in 2 or 3-dimensions by translation, rotation, reflection of glide reflection to obtain symmetry pattern

\section{The mathematics of complexity}

- Redesign the Frank Lloyd wright aline devine house from a non-planar to a planar graph structure and implement graph into a architectural plan

- Critical path analysis of the construction of a sailboat

[10] Williams, D.E. Natural Structure. Dover Press.

[11] Baracs, Janos, et al. Polyhedral Habitat. Structural Topology. No 2.

[12] Crapo, Henry. Mathematical Questions Concerning Zonohedral Spacefilling. Structural Topology. No 2.

[13] Edmund Scientific Barrington, N.J.

[14] Synestructics, Inc. Chatsworth, California.

[15] Pearce, Peter. Structure in Nature a Strategy for Design. M.I.T. Press, 1978.

[16] Pugh, Anthony. An Introduction to Tensegrity. Berkeley. University of California Press, 1976.

[17] Sedlek, Vinzenz. Paper Shelters. Structural Plastics Research Unit. University of Surrey. Guildford, England. 
[18] Salvadori, Mario. Why Buildings Stand Up. New York. Norton, 1980.

[19] Zodiac. No 21. 1971.

[20] Wachman, A., Burth, M. and Kleinman, M. Infinite Polyhedra. Technion, Haifa, 1974.

[21] Resch, Ron. The Ron Resch Paper and Stick Thing Film. Environmental Communication. Venice, California.

[22] Hilbert, D. and Cohn-Vossen, S. Geometry and the Imagination. New York. Chelsea Press, 1956.

[23] Salvadori, Mario. Structure in Architecture. Prentice Hall. 1975.

[24] Gheorghiu, A. and Dragomir, V. Geometry of Structural Forms. Applied Science Publishers. London. 1978.

[25] Beck, Anatole, et al. Excursions into Mathematics. Worth Publishers. 1969.
[26] Shuster, Seymour and Moser, W.O.J. Isometries. International Film Bureau Inc. Chicago, Illinois.

[27] Schattschneider, Doris. The Plane Symmetry groups: Their recognition and notation. M.A.A. Monthly, 85 (1978), 439-450.

[28] Shubnikov, A.V. and Koptsik, V.A. Symmetry in Science and Art. New York. Plenum Press, 1974.

[29] Ernst, Bruno. The Magic Mirror of M.S. Escher. New York. Ballantine Books. 1976.

[30] Coxeter, H.S.M. and Moser, W.O.J. Symmetries of a Cube. International Film Bureau Inc. Chicago, Illinois.

[31] Ore, Oystein. Graphs and their uses. Random House. 1963.

[32] Bellman, Lawrence, Cooke, K. and Lockett, J. Algorithms, Graphs, and Computers. New York. Academic Press. 1970.

[33] Noble, Benjamin. Applications of Undergraduate Mathematics in Engineering. MacMillan Press. 1967. 